\title{
都市郊外の居住環境における緑視率と住民による住居での花の装飾行動との関係 \\ Relationship between greenery in the field of vision and flower decorations behavior in urban residential environment
}

\author{
水上 象吾*
}

Shogo MIZUKAMI

\begin{abstract}
The purpose of this study was to verify whether flower decoration is one of the compensatory behaviors related to the demand for nature in urban areas. The relationship between the amount of greenery and the frequency of flower decorations in a residential environment was explored. I used presence of greenery in the field of vision as an indicator of the amount of greenery. It was found that greenery in the field of vision was correlated to the frequency of flower decorations. Residents who perceive the amount of greenery to be low tend to frequently participate in flower decorations. Land area is a limiting condition for the amount of greenery; however, land area did not affect flower decorations. The results show that flower decorations effectively function as a compensatory behavior.
\end{abstract}

Keywords: flower decoration, urbanization, compensatory behavior, demand for nature, greenery in the field of vision キーワード：花の装飾、都市化、代償行動、自然の希求、緑視率

\section{1. 研究の背景と目的}

日本においては、高度経済成長期より、水と緑等の環境づくり に関する政策が大都市圈の多くの基礎自治体により進められてき た。水や緑等の自然が都市の発展と共に失われ、居住環境に変化 が引き起こされたことは、都市住民に自然を意識的に求める行動 をもたらしたと言われる ${ }^{1)}$ 。自然を求める行動と都市化のかかわ りについては、都市の人口密度と自然鑑賞との関わりを示した研 究 ${ }^{1)}$ や親水行動と水辺環境との関係を明らかにした研究 ${ }^{2)}$ 等が蓄 積されている。これらの研究では、自然を求める行動要求に対し、 制限要因が働いた場合の行動様式の類型を示している。以上の文 献によれば、行動様式の類型は、「都市における自然の要求に対し、 変化した環境を物理的に元に戻寸回復行動、居住地における欠損 を一時的に他地域で充足させる分散行動や代替行動、空間の閉塞 にともない別の形態で欠損を補う代償行動等」があげられている。 例えば、都市の居住地における自然の減少に対しては、庭園・公 園等での代替、散策や旅行による一時的分散行動、小さな生け花 や鉢植えの植物などを求める代償行動があげられる。

本論では、自然を求める行動要求に対する代償行動として、住 居での花の装飾行動に着目する。

代償行動は、ある手段の行動が不可能になって主体がフラスト レートした場合にとられるとされる。代償行動が現れる条件とし ては、要求の強さ、元の動作と代償行動とが力学的に接触してい るか心理学的に分離しているかの程度、事態のルーズさの程度や 代償行動の困難度等があげられる ${ }^{3)}$ 。

居住環境における自然環境の減少に対し花を飾る代償行動に注 目すれば、自然への要求の強さが前提にあり、失われた自然環境 と花といら要素が共に自然要素として捉えられる点において代償 行動の条件となる。また、都市では自然の存在する空間を回復す ることが困難であるのに比べ、小さな花を飾る行動は狭い空間で も適応可能で容易であることから、代償行動として機能すると考 えられる。
ただし、花を飾る行為の要因は諸説ある。花の装飾としては、 衣食住、遊びや芸術などにおいて利用される側面があり、地位や 権威を示寸象徴表現など観念や信仰にかかわる側面もある。また、 古代洞窟壁画には動物は描かれているものの花が見られないこと 等から、花に対する美意識は生得的なものよりも後天的要因が強 いのではないかとの見方もある ${ }^{4)}$ 。本能的・文化的な要因という 捉え方に加え、個人属性による関心の差異も大きいと考えられる。

花の装飾の意味や要因は多様であると考えられるが、本論では、 室内での花の装飾を、居住環境における自然の寡少による代償行 動の現れの一つと捉え、環境要因と行動とのかかわりを検討寸る ことを目的とする。環境要因については、緑が都市の代表的な自 然要素と捉えられることから、具体的には、都市居住環境におい て、緑量の少ない環境では自然希求に対寸る代償行動の現れとし て、住民による花の装飾頻度が高まるとの仮説の検証を試みる。

\section{2. 研究の方法}

\section{(1) 対象地域}

調査は、都市における居住環境の緑量を測定し、アンケート調 査により住民の意識や行動を把握する。

都市の居住環境として、東京都町田市の戸建て住宅地域を対象 とした。町田市は郊外都市として発達し、これまで住宅の開発が 進んできた地域である。住宅地域の開発後、年月の経過は樹木の 生長等を促し、緑量が増加する傾向が認められる。その差異を環 境条件として考慮するため、開発年の異なる住宅団地を多く有し、 多様な環境条件の選定が可能な地域として対象を選定した。調査 対象として 43 の住宅団地を選定した。

調查対象とした住宅団地の開発年は、最古で 1944 年、最新は 2004 年であり、中央值は 1980 年となる。居住者の年齢層につい てはデータを得ていないが、2)に居住者を対象としたアンケート の回答者の年齢層 10 代区分を示す。

1) 緑視率の測定方法

*佛教大学社会学部公共政策学科 
緑を都市の代表的な自然要素とみなし、居住環境における緑量 を測定する。緑量評価の対象は、「日常的に認識される居住環境に 位置する身近な緑」であることが明らかにされており、「身近な」 とは、徒歩 5 分圈や距離として $250 \mathrm{~m}$ 圈程度の範囲に、緑に対す る意識の支配圈があると指摘されている ${ }^{11,12)}$ 。したがって、住宅 内部から見える緑量、庭の緑量や日常で接する緑など、対象とす る緑の範囲はさまざまあるが、本研究では住宅団地という数十メ ートル〜数百メートル圈の地域範囲を対象とし、身近な地域とし ての緑量を把握することで住民の意識や行動への影響を検討する。 対象とした住宅団地の面積は、平均 3. 3ha、中央值 2ha、最少值 0.5 ha、最大值 15.5 ha である。

緑量指標としては、緑に覆われた土地面積を表寸緑被率が自治 体の環境政策の基準や目標として一般的に用いられるが、住民に とっては視野内に映る緑量を表寸緑視率が緑の多少感に近いと考 えられるため、本調査では、緑量指標として緑視率を用いる。

緑視率測定のための写真撮影については、対象地域の公共の道 路上中央にて視線高の写真を $10 \mathrm{~m}$ 程度の閒隔にて、道路の進行方 向に沿って前後の写真を水平方向において撮影した。写真の撮影 方法は表 1 の通りである。

撮影の間隔単位を $10 \mathrm{~m}$ とした理由は、測定地点を多くし、地点 毎による誤差を少なくするためであり、街路景観における構造物 の変化頻度に関する研究 5) を参考に定めた。各写真内の植物の占 める割合を算出し、住宅団地ごとに全写真の測定值の平均を算出 し、その居住環境の緑視率とした。

2) アンケート調査

住民による花の装飾や緑に関する意識を把握するため、緑視率 測定と同住宅団地においてアンケート調査を行った。調査は戸建 て住宅を対象とし、質問票 1000 票を配布、517 票の回収を得た。 緑視率は、住宅団地の開発年からの年月の経過に起因すると想 定されるため、開発年の違いを多様に含むよう、対象地を選定し ている。したがって、質問票の配布は住宅団地の開発年代に配慮 した。1960 年代、1970 年代、1980 年代、1990 年代、2000 年代に 開発された住宅団地には 180 票ずつ配布し、1960 年より前に開発 された住宅団地は戸数が少ないため、100 票を配布し、合計 1000 票とした。年代 10 年区分の中での配布数は、宅地数に応じて分配 した。配布先の住宅のサンプリングは、ゼンリン住宅地図を用い た。対象とする住宅団地外の地域に接する建物を除き、残りの全 建物の中から無作為に選定した。配布時に空き家であることが確 認された場合、サンプリング時に選定されていない隣接する建物 ヘと変更した。

調査内容は、室内での花の装飾頻度、自宅や近所の緑量感、景 観に関する美意識、自然への関心の程度、個人属性となる性別・ 年齢等である。調査方法の概要を表 2 に示す。

回答者の性別は、男性 $43.0 \%$ 、女性 $57.0 \%$ である。年齢層は図 1 に居住年数を図 2 に示す。居住者を対象とした抽出方法が影響

\section{表-1 撮影緒元}

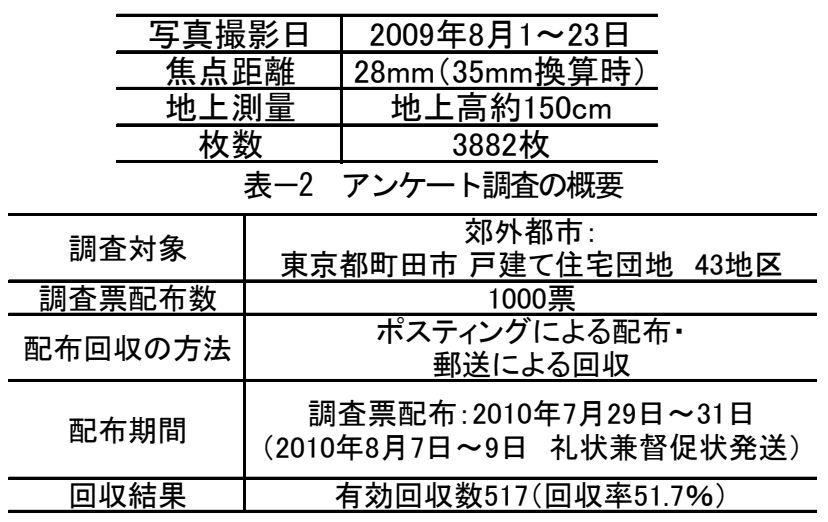

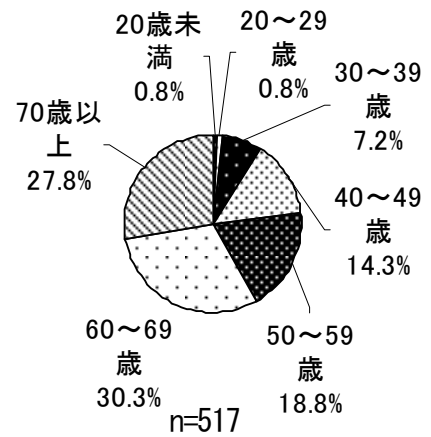

図-1 回答者年齢

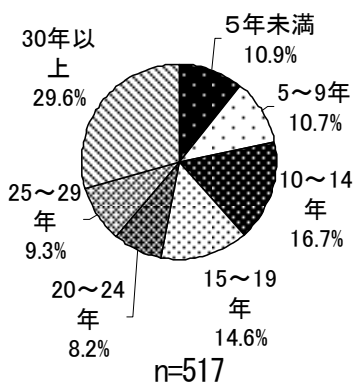

図-2 居住年数
したためか、回答者に年齢層が高い傾向があることは、本調査の 制約条件である。

\section{(2) 分析方法}

緑視率、建ぺい率や住宅地の開発年等の居住環境に関する客観 的データとアンケート調査による住民の主観的データとのかかわ りを明らかにする。

分析方法としては、相関分析を行う。客観的データは、住宅団 地ごとに捉えられるデータであり、アンケートのデータは住民 個々の回答データであるため、両者の関係を検討する際には、住 民個々のデータにその住民の居住する住宅団地のデータを対応さ せ分析した。本文における有意水準の表示は、**P $<.01 * \mathrm{P}<.05$ と し、数值 R は、pearsonの相関係数である。

\section{3. 分析結果}

\section{（1）環境要因と代償行動との関係}

1）緑量と花の装飾とのかかわり

緑視率測定の結果、全 43 の住宅団地の平均值は、11. $1 \%$ 、住宅 団地毎の最低值は $2.1 \%$ 、最大值は $20.4 \%$ であった。緑視率の心 理的評価に関しては、15\%〜35\%が人々の緑に対する充足感をも たらす水準であることが示されている ${ }^{6,7,8)}$ 。調査対象の地域は 戸建て住宅で指定建ぺい率は 30\%～60\%、多くは 40\%の低層住宅 であり、建ぺい率はそれほど高くはない。したがって、庭面積は 比較的広く確保されている地域であると考えられる。そのような 居住環境でさえ、緑視率の平均值は、充足感をもたらす水準と比 べ低いことから、現状の多くの居住環境では、充足感を満たす緑 量水準には達していないと考えられる。

つぎに、住居室内において花を飾る行動を把握するため、アン ケートによる質問文「室内に切り花や生け花を飾ることがありま すか。」との回答により行動の頻度を尋ね、4 選択肢にて回答を得 た（「よく飾る」44.1\%、「たまに飾る」39.4\%、「あまり飾らない」 12. $5 \%$ 、「飾らない $3.9 \% \mathrm{n}=510)$ 。

以上で得られた緑視率と花の装飾頻度との関係を、相関分析に より調べた。花の装飾頻度を「よく飾る」を 1 とし、「たまに飾る」 を2、「あまり飾らないを3、「飾らないを4 とする量的尺度と みなした。

相関分析の結果、有意な相関が認められた $(\mathrm{R}=-.183 * *)$ 。緑視 率が低、環境に居住する住民ほど、花を飾る頻度が多、傾向が示 された。花の装飾頻度4つの選択肢に対する緑視率を図3に示す。

また、近所の緑量感について、質問文「ご近所のみどりの量は どのくらいあると思いますか。」に対する回答「1. 多い、「2. や や多い、「3. やや少ない、「4. 少ない」の選択肢により回答を 得て (順に 20. 1\%，51.3\%，21.8\%，6.8\% n=513)、花の装飾頻度と の関係を相関分析にて調べた。その結果、近所の緑量感と花の装 飾頻度との間には、相関係数の值は小さいものの有意な関連が認 められた（R=-.096*)。 


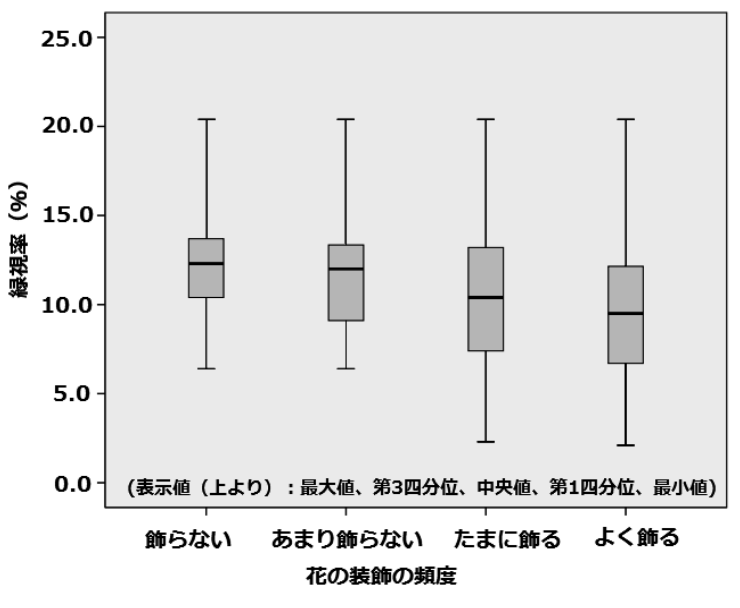

図-3＼cjkstart花の装飾頻度ごとの緑視率

同様に、自宅の緑量感についても、質問文「ご自宅の庭のみど りの量はどのくらいあると思いますかっ」に対する回答を近所の緑 量感同様の 4 選択肢にて把握し（順に $24.6 \%, 51.0 \%, 17.6 \%, 6.8 \%$ $\mathrm{n}=517$ ）、花の装飾頻度との関係を検討した。その結果、有意な関 係は認められたものの $(\mathrm{R}=.094 *)$ 、近所の緑量感の関係とは示さ れる傾向が逆方向であった。

以上の結果より、居住環境の緑視率が低く近所の緑量感が少な いと感じる住民ほじ、花を飾る行動が多くみられる。居住環境の 自然が少ないほじ、自然を求める代償行動として花を飾る行動が 引き起こされることが示唆される。

一方、自宅の緑量感については、緑量感と花を飾る行動とは正 の相関関係にあることが示された。自宅の庭は自ら所有する空間 であるため、居住地周辺とは異なり、自ら緑の増減をコントロー ルすることが可能なため、居住地周辺の自然が少ないと感じた結 果、緑量を増やす行動や花の装飾頻度を高めるなど、自然を求め る行動が可能となる。したがって、両指標が共に自然の享受を増 や寸方向へ正比例したのではないかと考えられる。

2）他の環境条件と花の装飾とのかかわり

自宅での緑量増加に関しては、樹木などを植栽するための敷地 面積が制約条件となると考えられる。切り花や生け花の装飾につ いては、多くの場合、広大な面積を必要とせず、空間的な制約は 弱いことが代償行動としての容易さを持つと考えられる。

本調査では住居ごとの敷地面積データは得られていないが、住 宅団地ごとの土地面積、および宅地数を把握した。道路や公園等 も含めた面積であり、宅地のみの面積ではないが、住宅団地の土 地面積を宅地数で除算し、各住宅団地における一戸あたりの土地 面積として把握した。

得られた一戸あたりの土地面積と緑視率との関係を相関分析に て調べたところ、有意な関係が示された $(\mathrm{R}=.367 * *)$ 。面積が広い 住宅団地ほど緑視率が高い傾向がある。

また、一戸あたりの土地面積と花の装飾頻度との関係を相関分 析にて調べた。結果、有意な関連は認められなかった。したがっ て花の装飾行動には空間の広さは制約条件となり得にくいことが 明らかとなった。

以上より、居住環境において緑量を多く確保するには土地面積 が制約条件となるが、室内での花の装飾行動には、土地面積その ものとは無関係に、緑量の充足が関連すると考えられる。つまり、 土地面積が確保される結果として緑量が充足するかどうかが花の 装飾行動に対する要因となり得る。ゆえに、都市という限られた 空間内で、緑の減少に対する要求として生け花や切り花の装飾を 行うことは、代償行動として有効に機能し得ると考えられる。
また、1）にて、緑視率が低い居住環境ほど花の装飾頻度が多い 傾向がみられたが、緑視率の増加は年月の経過による樹木の生長 等に依存する傾向がある。それゆえ、本調査では宅地の開発年の 差異を検討する。

住宅団地の開発年と花の装飾頻度との関係を相関分析により検 討した。分析の結果、有意な関係が認められた ( $=.203 * *) 。$

また、住宅団地の開発年と緑視率との関係を相関分析にて調べ たところ、有意な相関が認められ、強い関連がみられる $(\mathrm{R}=-.518 * *)$ 。開発の古い住宅団地ほど緑視率が高い傾向がみら れる。開発されたばかりの宅地は、更地に造成されることが予想 され、緑が少ない環境になり、年月の経過によって樹木等の緑が 生長し、緑量が増加すると考えられる。したがって、開発が新し い場所ほど緑が少なく、結果として花の装飾頻度が多くなると考 えられる。ただし、居住環境の環境条件以外にも、個人属性の違 い等、花の装飾行動に影響を与える要因がある。そこで、つぎに 花を飾る行動と個人属性との関係を探る。

\section{（2）個人属性と花の装飾との関係}

性別・年齢や自然への関心等、個人属性の違いが、花の装飾頻 度へ与える影響を検討する。

まず、性別と年齢による装飾頻度の差異を検討した。性別にお いては、男性、女性の 2 分類、年齢は、20 歳未満と 20 歳代の回 答者数が少ないため、再カテゴリ化を行い、30 歳代と同区分とし、 40 歳代、50 歳代、60 歳代、70 歳以上の計 5 分類とした。

花の装飾頻度との関係を相関分析にて調べたところ、性別との 間に有意な関係は認められなかった。一方、年齢との間には有意 な関係が認められた $(\mathrm{R}=-.373 * *)$ 年齢が高いほど、花を飾る頻 度が多い。年齢区分ごとの花の装飾頻度の割合を図 4 に示す。

本論では、装飾される花の入手方法については限定していない。 したがって、購入に限らず、庭での栽培等の可能性もあると考え られるが、花の購入に関しては既存研究において、所得や価格の 影響があること ${ }^{9)}$ 、主な目的が屋内装飾であり支払い金額は年 齢・性別による違いがあることが示されている ${ }^{10)}$ 。

花を都市で得られる自然要素の一つと捉えると、自然への関心 の程度といった個人の趣向等の影響も花の装飾行動に関わる可能 性がある。そこで、自然への関心を 4 段階の回答により把握し(関 心がある」64.0\%、「やや関心がある」32.6\%、「あまり関心がない」 3. 3\%、「関心がない」 $0 \% \quad n=511$ )、花の装飾頻度との関係を相関分 析により調べた。

結果、有意な関係が示され相関係数も高い $(\mathrm{R}=.382 * *)$ 。自然に 関心がある人ほど、花を飾る頻度が多い傾向が示された。図 5 に、 自然への関心の回答区分ごとに分類した花の装飾頻度を示す。

また、花は美の象徵とされることから、環境に対する美意識等 が、装飾行動に関与寸る可能性がある。そこで、居住環境に対す

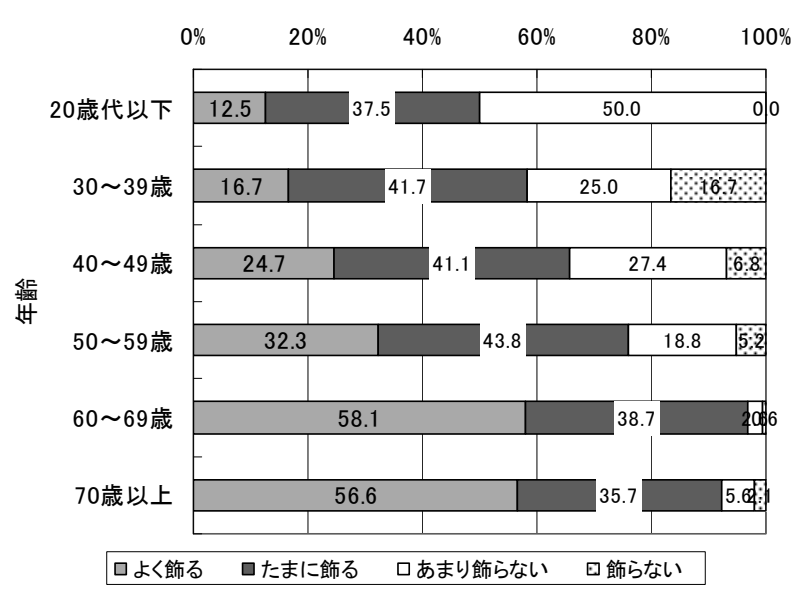

図-4 年齢区分ごとの花の装飾頻度の割合 


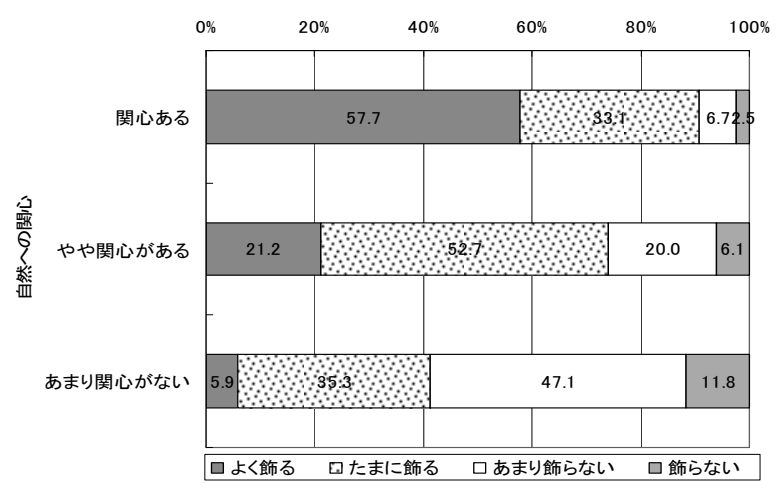

図－5 自然への関心の程度による花の装飾頻度の差異

る美意識を、質問文「街並みの景観には調和が大切だと思います か。」による回答「大切」「やや大切」「あまり大切ではない」、 「大切ではない」の4 段階により調べ (順に 77.2\%, 22.2\%,0.6\%, $0 \% \mathrm{n}=517$ ）、相関分析により花の装飾頻度との関係を調べた。

分析の結果、有意な関係が示された $(\mathrm{R}=.222 * *)$ 。景観の調和を 大切と思う人ほど、花の装飾頻度が高い傾向が示された。環境に 対する美意識も花という美的な対象の装飾にかかわる興味や行動 に関与している可能性がある。

\section{（3）環境条件と個人属性を含めた要因の影響}

居住環境における花の装飾行動は、年齢や自然への興味関心な どの個人属性の違い、環境に対する美意識等が関与することが示 されたが、居住環境の緑量が少ないことが関連していることも示 唆された。

しかし、これらの要因群と花の装飾行動との関連は、2 変数間 での相関関係を検討したに止まる。変数間の一対どうしでの相関 分析では疑似相関の可能性が残るため、つぎに、重回帰分析によ り、多数の要因の影響を加味した場合に花の装飾行動に独立の効 果を持つ要因を明らかにすることとする。

花の装飾頻度を従属変数とし、前節までに相関関係のみられた 変数として「自然への関心」、「景観の調和意識」「年齢」、「近所 の緑量」「緑視率」「住宅団地の開発年」を独立変数として重回 帰分析を行った。

ただし、すべての独立変数を投入したところ、開発年と緑視率 の変数に共線性が認められた。開発年と緑視率との変数間に強い 関連がみられること、および、開発年が花の装飾行動と関連する ことは住宅団地の緑視率を介して影響していると考えられること から、投入する变数から開発年を除き重回帰分析を行った。

分析の結果、決定係数 $\mathrm{R}^{2}=.236$ のもとに有意な関係が認められ、 花の装飾頻度にかかわる要因の影響が認められた (表 3 参照)。各 独立変数の説明力を標準偏回帰係数にみると、「自然への関心」

「年齢」という個人の属性にかかわる変数の影響が 0.273 と 0.231 と高い数值が示された。ついで、「緑視率」の係数が-. 104 と 3 番 目に高いことが示された。

ただし、本結果の決定係数の值は高くはない。本論で取り上げ た環境要因としての緑視率の多寡、個人の基本属性としての年齢 や興味関心などの啫好の他にも、花の装飾行動の要因となる環境 条件や行動要因が潜在すると考えられる。

行動要因一つとして、本論の背景に述べた「要求を他地域で充

\section{表－3＼cjkstart花の装飾頻度を説明する重回帰モデル}

\begin{tabular}{c|c|c|c|c}
\hline 従属変数: & 花の装飾頻度 & 標準偏回帰係数 & $\mathrm{t}$ 値 & 有意確率 \\
\hline 独立変数: & 自然関心 & .273 & 6.318 & 0.000 \\
& 景観調和 & .100 & 2.403 & 0.017 \\
& 年齢 & .231 & -5.081 & 0.000 \\
& 近所緑量 & -.056 & -1.338 & 0.182 \\
& 緑視率 & -.104 & -2.388 & 0.017 \\
\hline $\mathrm{R}=.486$ & $\mathrm{R} 2=.236$ & 0.000 \\
\hline
\end{tabular}

足させる分散行動や代替行動」が考えられる。本調查においては、 分散行動や代替行動を把握する目的にて、公園や緑地での行動頻 度を把握している。質問文「あなたは、家の近くの公園や緑地に どのくらい行かれますか。」に対する回答を尋ね、4 選択肢にて回 答を得た (「1.よく行く」25.5\%、「2.たまに行く」44.1\%、「3.あま り行かない $22.5 \%$ 、「4.ほとんど行かない $7.8 \% 、 n=517)$

しかし、この「公園や緑地での行動頻度」変数は、相関分析に おいて、緑視率や花の装飾頻度との間に有意な相関関係が認めら れなかった。

\section{5. 考察}

本研究では、都市における住居での花の装飾行動は、自然の要 求に対する代償行動の現れであるとの考えに基づき、居住環境の 自然要素として緑視率と住民の意識や行動との関連を検証した。

緑視率が低い居住環境ほど、花の装飾頻度が多い傾向が認めら れる。花の装飾行動には、年齢、自然への関心や美意識などの個 人属性による違いも関連した。そのため、以上の要因を同時に投 入し、独立の効果を持つ要因を明らかにした。その結果、緑視率 と花の装飾行動とには関連があることが示された。土地面積その ものとは無関係に、緑量の充足が要因となり得ることから、花の 装飾行動は代償行動として機能している可能性がある。

ただし、多要因の影響を踏まえた分析結果の決定係数は高くな いことから、花の装飾という行動を引き起こす他の要因も潜在し ていると考えられる。例えば、自然の要求に対して、公園や緑地 での分散・代替行動等が影響する可能性がある。本分析では、そ の影響は示されなかったが、公園や緑地での行動目的は多岐に及 んでおり、行動に関わる個人属性なども複合的に関連するため、

「自然の要求に対寸る公園や緑地での行動」としては明らかにな らなかったと考えられる。

既存研究では、自然の豊かな環境へ赴く旅行などの影響も示唆 されていることから ${ }^{11} 、 今$ 後、多様な行動の影響を捉え、それら の行動がどのような要因により規定されるのか等、影響の範囲を 明らかにできるよう条件を設定し分析していく必要がある。

\section{補注及び引用文献}

1）品田穣・立花直美・杉山恵一 (1987) : 都市の人間環境: 共立出版, $265 \mathrm{p}$

2）畔柳昭雄・渡辺秀俊（1999）: 都市の水辺と人間行動一都市生態学的 視点による親水行動論 : 共立出版, 236pp

3）中村勝（1971）：代償行動論序説 (理論)：日本教育心理学会総会発表 論文集 (13)，12-13

4) 日高敏隆・白幡洋三郎 (2007) : 人はなぜ花を愛でるのか : 八坂書房, $270 \mathrm{pp}$

5）青木陽二 (1989) : 街路における緑量感の分析 : 環境情報科学, 18-1, 91-95

6）位寄和久・小玉祐一郎・安立植・大橋征幹（1990）: 住宅地計画にお ける自然環境の保全と利用に関する研究（その8）住宅地の緑視環境 予測と評価手法 : 建築学会梗概集, 215-216

7）松浦彰一(1980):みどり環境の計量化の試み:都市計画, No. 109, 22-2

8）武田雅次（1985）: 街路樹の適量は: グリーンエイジ 2(5), 21-23

9) 辻和良 (2000) : 切り花の消費動向と消費者の購買行動 : 和歌山県農 林水産総合技術センター研究報告 (1), 111-119

10）山本晃郎（1992）: 都市住民の花きに対寸る購入行動・意向と産地の 実態からみた花き産地の再編方向 : 岡山県立農業試験場研究報告 (10), $17-25$

11）丸田頼一・島田正文・阿部邦夫（1984）: 緑を中心とした都市景観の 構成に関する研究 : 造園䧱誌，47(5)，201-206

12）李榮大・浅川昭一郎 (1990)：緑の満足度評価における実験計画法の 適用について : 造園杂㑊誌，53（5），383-388 